\title{
Kezdeti tapasztalataink az MR-artrográfiával
}

\author{
Sallai Imre dr. ${ }^{1}$ - Nagy Ádám ${ }^{1}$ - Szatmári Attila dr. ${ }^{1}$ - Kocsis György dr. ${ }^{1}$ \\ Huszár Andor dr. ${ }^{2}$ - Kovács Dániel Tamás dr. ${ }^{2}$ - Kalina Ildikó dr. ${ }^{2}$ \\ Zsiga Görgy dr. ${ }^{2}$. Antal Imre dr. ${ }^{1}$ - Skaliczki Gábor dr. ${ }^{1}$ \\ ${ }^{1}$ Semmelweis Egyetem, Általános Orvostudományi Kar, Ortopédiai Klinika, Budapest \\ ${ }^{2}$ Semmelweis Egyetem, Általános Orvostudományi Kar, Orvosi Képalkotó Klinika, MR Diagnosztikai Részleg, \\ Budapest
}

Bevezetés: A vállsebészeti képalkotó diagnosztika „arany standardja” a mágnesesrezonancia-képalkotás (MRI). A konvencionális MRI szenzitivitása teljes vastagságú szakadások esetében $85 \%$ fölötti, a részleges rotátorköpeny-szakadás esetében ennek csupán a fele. Hasonlóan alacsony a diagnosztikai pontossága az elülső labrumlaesio különböző variációinak detektálásában, továbbá a glenohumeralis szalagok sérülésekor is. Az ízületbe adott direkt kontrasztanyag ezeket a diagnosztikai pontatlanságokat javítani tudja.

Módszer: A Semmelweis Egyetemen 2018 februárjában végeztük el az első vállízületi MR-artrográfiát. A vizsgált időszak 17 hónap volt, mely idő alatt huszonkilenc $(n=29)$ vizsgálat történt. Az ízület feltöltése röntgenátvilágító kontrollja alatt, perkután technikával történt. A feltöltéshez gadolíniumalapú kontrasztanyagot használtunk.

Eredmények: A vizsgált 29 betegnél a beadott kontrasztanyag 26 esetben $(89,9 \%)$ jó pozíciót, valamint jó distensiót mutatott. Az összes vállízületi vizsgálat közül 9 esetben (31\%) végeztünk mútéti beavatkozást; a mútéti kép alapján felállított diagnózisok 8 esetben $(88,9 \%)$ megegyeztek a radiológiai véleménnyel.

Következtetés: Az intraarticularis térbe adott kontrasztanyag az ízületben lévő struktúrák láthatóságát és megítélhetőségét jelentősen javítja; beadása röntgenátvilágító kontroll segítségével biztonságos, az ízületből rövid idő múlva felszívódik, eddigi tapasztalataink szerint problémát utólag nem okoz. A natív MR-vizsgálattal nehezen megítélhető sérülések felismerését jelentôsen javítja, a mútét előtti tervezést segíti.

Orv Hetil. 2020; 161(36): 1514-1521.

Kulcsszavak: artro-MR, direkt kontrasztanyag, rotátorköpeny-szakadás

\section{Our initial experiences with MR arthrography}

Introduction: The gold standard method for shoulder surgery imaging is magnetic resonance imaging (MRI). The sensitivity of the conventional MRI for full thickness tears is way above $85 \%$, for partial rotator cuff lesions this number is less than $40 \%$. Diagnostic accuracy is equally low in detecting different variations of anterior labrum lesion and also in injury of the glenohumeral ligaments. Contrast agent given directly into the joint can improve these diagnostic inaccuracies.

Method: We made the first shoulder joint related MR arthrography in February 2018 at the Semmelweis University. The studied period lasted for 17 months; during that time 29 examinations were performed. For the injection we used gadolinium-based contrast substance.

Results: In the case of 26 patients (89.9\%), the contrast substance had a good position and distended well. From all of the shoulder MRI examinations, 9 (31\%) surgical interventions were made, and 8 surgical findings had the same diagnosis as the radiologic description.

Conclusion: The contrast substance given into the intraarticular space makes it easier to identify and detect the structures in the joint. The injection under X-ray screening is safe, it is absorbed from the joint in short time, and so far - based on our experience - there has not been any complication. It can help to identify injuries which are difficult to diagnose with conventional MRI, and helps planning before surgery.

Keywords: artro-MR, intraarticular contrast agent, rotator cuff tear

Sallai I, Nagy Á, Szatmári A, Kocsis Gy, Huszár A, Kovács DT, Kalina I, Zsiga Gy, Antal I, Skaliczki G. [Our initial experiences with MR arthrography]. Orv Hetil. 2020; 161(36): 1514-1521.

(Beérkezett: 2020. március 12.; elfogadva: 2020. április 11.) 


\section{Rövidítések}

ABER = (abduction external rotation) abdukciós kirotációs helyzet; ALPSA = anterior labral periosteal sleeve avulsion; CT = (computed tomography) számítógépes tomográfia; ESSR = European Society of Skeletal Radiology Sports Sub-committee $;$ FatSat $=($ fat saturation $)$ zsírtelítettség; GLAD = glenolabral articular disruption; HAGL $=$ humeral avulsion of the glenohumeral ligament; IGHL = inferior glenohumeral ligament; MDCT $=($ multiple detector CT $)$ multidetektoros CT; $\mathrm{MR}=$ (magnetic resonance) mágneses rezonancia; $\mathrm{MRI}=$ (magnetic resonance imaging) mágnesesrezonancia-képalkotás; $\mathrm{PD}=$ (proton density) protonsürüség; SLAP = superior labral anterior posterior; STIR = short Tl inversion recovery

A vállízület fájdalmának és funkcióvesztésének vagy mozgáskorlátozottságának hátterében különböző mechanizmussal létrejött változatos patológiák állhatnak. A leggyakoribb elvátozások közé tartozik a teljes vagy részleges vastagságú rotátorköpeny-szakadás, illetve a vállízületi instabilitást okozó labroligamentosus sérülések. A pontos diagnózis felállításához elengedhetetlen a megfelelő képalkotás. Elterjedt, olcsó és hasznos eljárás az ízületi ultrahang, ez azonban nem alkalmas az összes struktúra láthatóvá tételére, ezért a fizikális vizsgálat után a képalkotó diagnosztikában jelenleg elsőként választandó módszer a konvencionális, natív mágnesesrezonancia-képalkotás (MRI). Mind az ultrahangvizsgálat, mind az MRI meglehetősen pontos a teljes vastagságú rotátorköpeny-szakadások esetében, a legtöbb tanulmányban azonban szó esik arról, hogy részleges rotátorköpeny-szakadásoknál, valamint a labroligamentosus komplex sérüléseinél jelentôs korlátokba ütköznek [1]. Fontos lenne ugyanakkor ezeknek a sérüléseknek a felismerése is [2], mivel sebészeti vagy konzervatív kezelésük kiváló eredményeket hoz.

Az MR-atrográfia alkalmas módszer arra, hogy ezeket az egyéb vizsgálóeljárással nehezen vizualizálható sérüléseket láthatóvá tegyük. Ennek oka az, hogy a direkt módon bejuttatott kontrasztanyag az esetleges patológiás tereket is kitöltve szétoszlik az ízületben, így könnyítve meg a diagnózis felállítását. Teljes vastagságú szakadás során kijut az ízületből, megmutatva a szakadás helyét. Fontos a kontrasztanyag disztendáló funkciója is, mely az ízületben lévő terek tágításával javítja a képalkotás részletgazdagságát.

Közleményünk elsődleges célja az általunk elvégzett összes vállízületi MR-artrográfiás vizsgálat képanyagának és eredményének áttekintése, amennyiben mütétet végeztünk, a radiológiai lelet és a mútéti diagnózis összehasonlítása, valamint annak összegzése, hogy az elvégzett vizsgálatok milyen hatékonysággal javítják a műtéti indikációk, valamint a mútéti terv felállítását. Másodlagos célja pedig kiválasztott képanyagon keresztül bemutatni egy-egy jellegzetes patológiás struktúrát.

A vizsgálat indulásakor feltételeztük, hogy bizonyos válogatott esetekben az MR-artrográfia több és pontosabb információt szolgáltathat az ortopéd sebész számára nehezen diagnosztizálható esetekben.

\section{Módszer}

A vizsgálatok kivitelezése a Semmelweis Egyetem Ortopédiai Klinikájának és Orvosi Képalkotó Klinikája MR Diagnosztikai Részlegének együttmúködésével történt. A betegek bevonása 2018. februártól 2019. július végéig tartott (17 hónap). Eleinte döntően vállízületi panaszokkal érkező betegeken végeztük el a vizsgálatot, a későbbiekben azonban térd-, valamint egy-egy alkalommal csípő- és csuklóízületet is vizsgáltunk.

Az MR-artrográfiás vizsgálati folyamatot két fázisra oszthatjuk. Az első az elókészítési fázis, melynek során a kontrasztanyag bejuttatása történik az ízületbe röntgenképerősítő alatt (a vizsgálóberendezés típusa: Luminos Agile; Siemens, München, Németország). A kiválasztott ízületbe szabályos bőrfertőtlenítés után ízületi punkcióval juttattuk be az előkészített, gadolíniumalapú kontrasztanyag-keveréket - $11 \mathrm{ml}$ fiziológiás sóoldatban feloldott $8 \mathrm{ml}$ Omnipaque 350, valamint 0,2 ml Dotarem -; az elegy végtérfogata kb. $20 \mathrm{ml}$ volt. Fontos a megfelelö légtelenítés, mert a bejutó apró légbuborékot a képek kiértékelésekor ízületi idegen testként értelmezhetjük. Preferáltuk a jódos és a gadolíniumalapú kontrasztanyag egy oldatban való beadását, így tovább csökkenthetjük a felesleges levegő bejutási esélyét. Kiemelendő továbbá a gadolíniumalapú kontrasztanyag megfelelő hígításának elérése a fentiek szerint. Amennyiben túl tömény a gadolíniumtartalmú oldat, úgy a várthoz képest ellenkező hatást érünk el: a kontrasztanyag $\mathrm{T}_{1}$-jel-adása alacsony lesz (növeli a $\mathrm{T}_{1}$-relaxációs időt) [3]. A beadott kontrasztanyag mennyisége az ízület nagyságától függ. Célunk az ízület disztendálása volt, ám nem volt célunk a szükségesnél nagyobb diszkomfort létrehozása. Ezt az elvet követve a vállízületbe $12-15 \mathrm{ml}$, a térdízületbe $8-10 \mathrm{ml}$, a csípóízületbe 5-8 ml, a csuklóízületbe 1-2 ml kontrasztanyagot adtunk.

Az ízületi punkciók során standard anatómiai pontokat használtunk tájékozódásként, és szintén standard behatolási pontokon végeztük az ízület szúrását [4].

A vállízület esetében hanyatt fekvő helyzetben, teljesen kirotált karral megkerestük az érintett oldali processus coracoideust. Ettől $1 \mathrm{~cm}$-rel distalisan és $1 \mathrm{~cm}$-rel lateralisan találtuk a behatolási pontunkat.

Képerősítő-ellenőrzéssel a tû hegye a humerusfej felső-medialis kvadránsára mutatott (1. ábra). Kirotált kar esetében ez a pont a rotátor-intervallumba esik. A tü beszưrása után megkezdtük képerósítő kontrollja mellett a kontrasztanyag beadását: a jó pozíciót az igazolta, ha a kontrasztanyag beadása során az axillaris recessus kezdett el telődni. Alternatív megoldás lehet az ízületbe adott injekció képalkotóval való vezérlésére és ellenőrzésére az ultrahangkészülék, mely könnyebben elérhető, gyorsabb az előkészület, nem jár sugárterheléssel, és a nemzetközi irodalomban talált egyes adatok szerint az első próbálkozás pontossága is magasabb [5].

Az első, előkészítési fázis után következett a második fázis, maga az MR-vizsgálat (a berendezés típusa: Inge- 


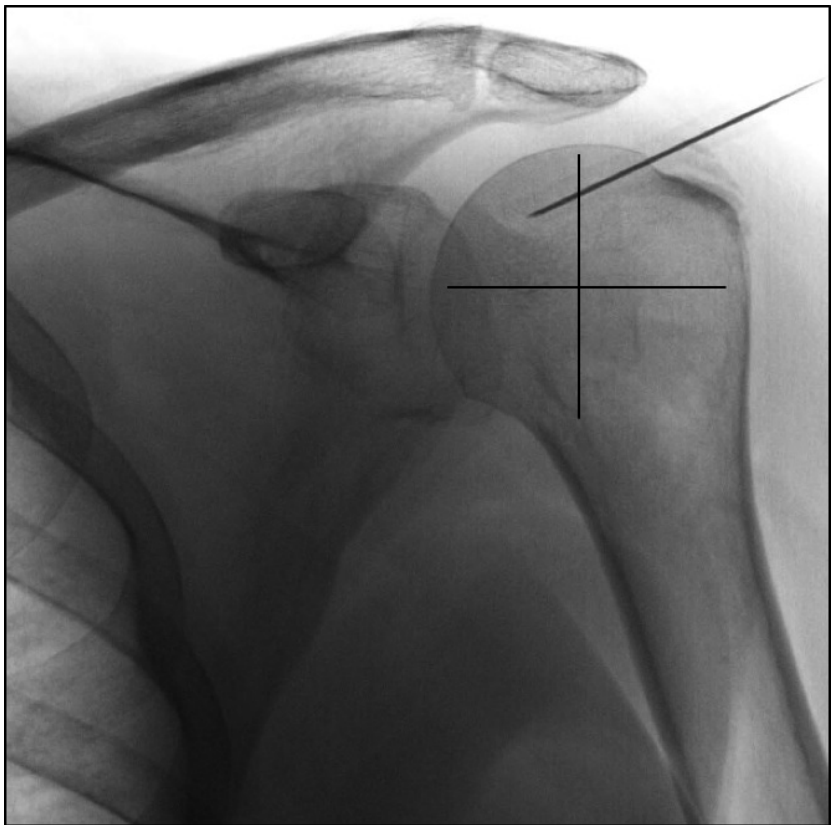

1. ábra

Képerősítő vezérlésével a humerusfej felső, medialis kvadránsára célzunk

nia 1,5 tesla; Philips, Amszterdam, Hollandia) [6], melyet a kontrasztanyag beadását követő maximum fél órán belül megkezdtünk; ez a hosszúságát tekintve egy normál, natív MR idejét vette igénybe. Fontos kiemelni, hogy míg az indirekt (intravénás kontrasztanyagos) artrográfiánál a synovialisan kiválaszott kontrasztanyag egyenletes eloszlása érdekében fontos az ízület jó bemozgatása/tornáztatása a vizsgálat előtt, addig a direkt artrográfiánál - a mi vizsgálatunkban is - a beteg a túl sok mozgatással kipréselheti az ízületból a beadott kontrasztanyagot; így a vizsgálat korlátozott értékü lehet, vagy teljesen elvesztjük a kontrasztanyag adta előnyöket. Az MR-vizsgálatokhoz a beteg megfelelő pozicionálása alapvető fontosságú [7]. A vállízület példáján bemutatva: a beteg a karját a teste mellett tartotta, a vállízület pedig kirotációban volt, a punkciónál használt pozícióhoz hasonlóan. A túlzott kirotáció kerülendő. Megfelelő helyzet mellett az elülső labrum és a rotátorköpeny is jól megítélhető, míg ezek a struktúrák berotáció mellett csak korlátozottan értékelhetők. Opcionálisan használható pozíció az abdukciós kirotációs helyzet (abduction external rotation - ABER), melyet úgy érhetünk el, ha beteg a karját fejre vagy tarkóra teszi. Ez a pozíció elősegíti többek között az IGHL-sérülések, a Perthes-laesiók, a rotátorköpeny articularis felszíni laesiók és a coracohumeralis szalag megítélését, elfedhet azonban egyéb laesiókat (például ALPSA), így csak kiegészítő pozícióként alkalmaztuk. A vállrégióhoz dedikált tekercseket alkalmaztunk.

A vizsgálatokhoz használt szekvenciákat és leképzési síkokat a European Society of Skeletal Radiology Sports Sub-committee (ESSR) ajánlása, a helyi igények és az elérhető technikák figyelembevételével terveztük meg [8].
A helyes vizsgálati síkok kijelölésének alapja a megfelelő ferde coronalis sík kijelölésével kezdődik, melynek a scapula testével vagy a supraspinatus ín lefutásával kell párhuzamosnak lennie. Ideális esetben ilyenkor az erre meróleges ferde sagittalis sík a glenoid és a labrum síkjába esik.

\section{Betegek}

A fent nevezett idő alatt 29 vállízületi MR-artrográfiás vizsgálatot végeztünk. Az átlagéletkor 42,8 év volt. A legfiatalabb beteg 16 éves, a legidősebb 73 éves, a számolt standard deviáció 15,28 volt. Az anamnézisben 17 esetben $(58,6 \%)$ szerepelt trauma, a legtöbb esetben sportoláshoz kapcsolódó egyszeri vagy rekurrens vállficamok. 9 esetben végeztünk mütétet, míg 20 esetben konzervatív kezelés történt. A kontrasztanyag-beadások során allergiás reakciót vagy szeptikus szövődményt nem észleltünk. Egy beteg számolt be elhúzódó fájdalmakról a kontrasztanyag beadása után, amelyek 3-4 nap alatt teljesen megszüntek. Átlagosan $15 \mathrm{ml}$ kontrasztanyag került beadásra; a beadás az elókészítéssel együtt átlagosan 15 percet vett igénybe.

\section{Eredmények}

Az elvégzett vizsgálatokat független radiológusok leletezték és értékelték (2. ábra). Az ízületi punkció során bejuttatott kontrasztanyag radiológus által történt megítélése az elkészült képanyagon 26 esetben (89,9\%) jó pozíciót, valamint jó distensiót mutatott, 3 esetben $(10,1 \%)$ vagy az ízület distensiója nem volt elegendő, vagy a kontrasztanyag beadásakor a pozicionálás közben került ízületen kívülre a kontrasztanyag. Labrumdegeneratiót 8 esetben $(29,6 \%)$ találtak, Bankart-laesiót 2 $(7,4 \%)$, ALPSA-laesiót $2(7,4 \%)$, SLAP-laesiót 3 (11,1\%), reverz Bankart-laesiót 1 (3,7\%) esetben írtak le. A rotátorköpeny-érintettség a következőképpen alakult: 4 esetben $(14,8 \%)$ részleges, 4 esetben $(14,8 \%)$ teljes vastagságú rotátorköpeny-szakadást véleményeztek, a m. biceps brachii caput longum szakadását 3 esetben $(11,1 \%)$ írták le. 2 esetben nem igazolódott eltérés.

Az összes beteg közül 9 esetben végeztünk vállartroszkópiát, a többi esetben konzervatív kezelés, gyógytorna történt. A mútéti kép alapján felállított diagnózisok 8 esetben $(88,9 \%)$ megegyeztek a radiológiai véleménnyel. Egy esetben $(11,1 \%)$ szerepelt a m. supraspinatus ín szakadása, mely az artroszkópia során nem volt felfedezhető.

\section{Részleges és teljes vastagságú rotátorköpeny-szakadás}

A részleges rotátorköpeny-laesio esetében (3/A ábra) az ízületbe adott kontrasztanyag az ízületben marad, miközben jól láthatóan kirajzolja a rotátorköpeny ízületi 


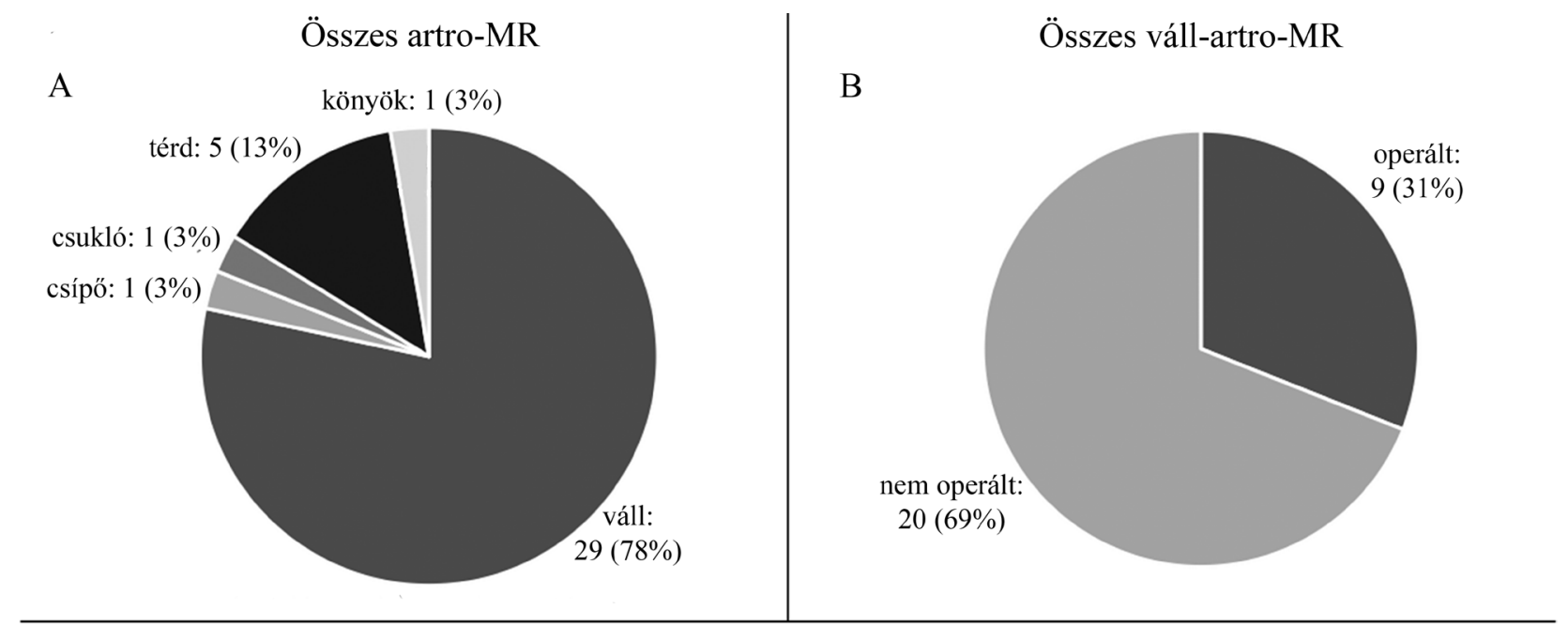

C

Radiológiai diagnózisok előfordulása

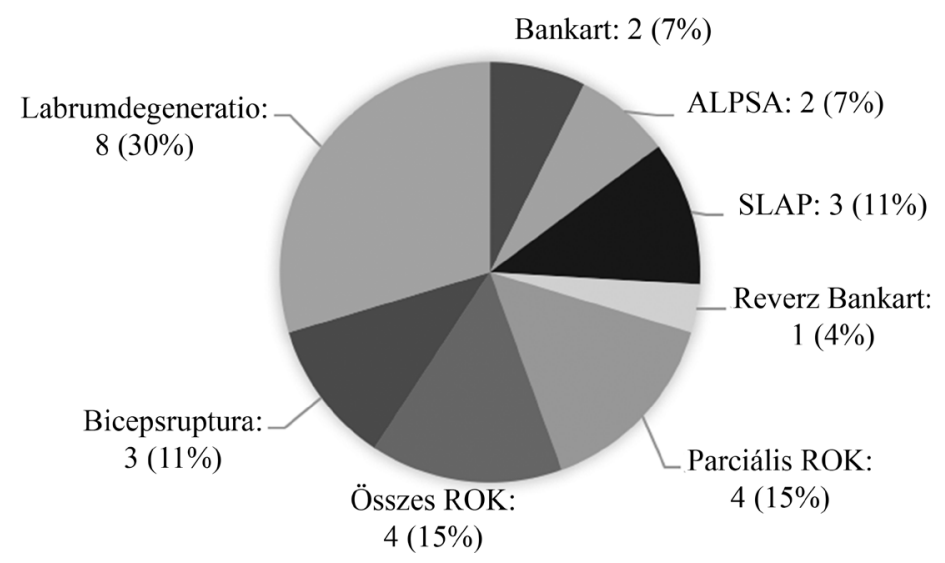

2. ábra

Az eredmények összesítése

ALPSA = anterior labral periosteal sleeve avulsion; $\mathrm{MR}=$ mágneses rezonancia SLAP = superior labral anterior posterior; $\mathrm{ROK}=$ rotátorköpeny

oldalán lévő egyenetlenségeket, melyek a képen látható esetben a m. supraspinatus inát érintik; az érintett rostok a 'rotator cable'-ig visszahúzódtak. Teljes vastagságú rotátorköpeny-szakadás esetén $(3 / B$ ábra) az ízületbe adott kontrasztanyag a subacromialis, illetve a subdeltoidalis bursában is megjelenik, miközben jól követhetően kirajzolja, hogy melyik ponton lépett ki a glenohumeralis ízületből (nyíl).

\section{ALPSA-laesio}

A 4. ábra az ALPSA, vagyis az 'anterior labrum periosteal sleeve avulsion' patológiáját ábrázolja. Az MR-artrográfiás vizsgálat során a kontrasztanyag az vállízületet jól disztendálta; sagittalis nézetben (4/A ábra) az elülső labrum 9-tôl 7 óráig tartó, diszlokációval járó szakadása ábrázolódik, a horizontális metszetben $(4 / B$ ábra) kiegészítésként jól látszik, hogy a labrumhoz kapcsolódóan a glenoid elülső peremén lévő periosteum is feltépett, de még a csontos felszínhez kapcsolódik. Az artroszkópos vállmútét során talált lelet (4/C ábra) ezzel megegyező volt.

\section{Megbeszélés}

A Semmelweis Egyetem Ortopédiai Klinikájának és Orvosi Képalkotó Klinikája MR Diagnosztikai Részlegének együttmúködésével 2018. februárban végeztünk először MR-artrográfiás vizsgálatot. Azóta összesen 29 válogatott esetben történt hasonló beavatkozás. Ekkora elemszámú csoport elemzése nem alkalmas statisztikai következtetések levonására, de az eddigi eredmények alapján az MR-artrográfia megbízhatóan jelzi előre a vállízületi elváltozásokat.

A vállízületi képalkotásban elterjedt ultrahang- és MRvizsgálatok diagnosztikai értéke bizonyos sérülések esetén (részleges rotátorköpeny-szakadás, labrum glenoidale sérülés) [9] nem megfelelő, ezért az utóbbi időben egyre inkább teret nyer az MR-artrográfia.

Alternatív megoldásként mindenképpen meg kell említenünk az MDCT-artrográfiát, mely olcsóbb, a vizsgálati időt tekinve rövidebb, jól ábrázolja a glenoid peremtöréseket és porcsérüléseket, HAGL-laesiókat. Az Acid és munkacsoportja által végzett prospektív vizsgálatban 40 betegen hasonlították össze az MDCT- és MR-art- 


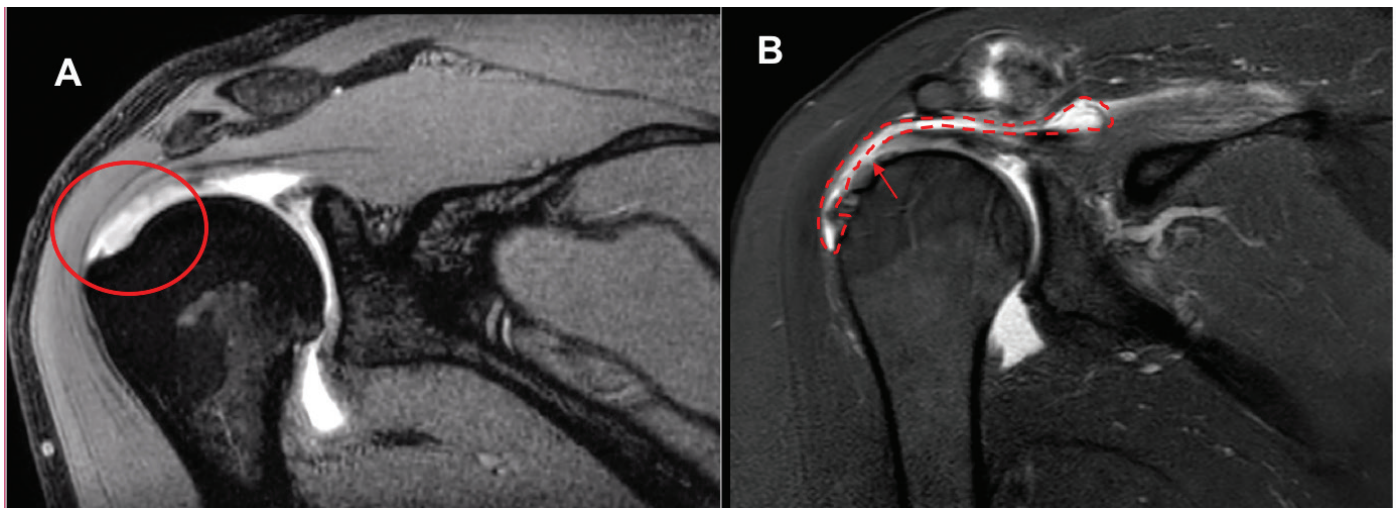

3. ábra

A) Részleges rotátorköpeny-szakadás: az érintett rostok a 'rotator cable'-ig retrahálódtak (piros kör: a szakadás területe). B) Teljes vastagságú rotátorköpeny-szakadásnál az ízületbe adott kontrasztanyag a subacromialis és subdeltoidalis bursába jutott ki (szaggatott vonal: a subacromialis és subdeltoidealis bursában elhelyezkedő kontrasztanyag; nyíl: a szakadás helye, ahol a kontrasztanyag kilép az ízületből)

rográfia során kapott képanyagot artroszkópos mútét során kapott leletekkel. Összehasonlításukban az MDCT-artrográfia pontosabbnak mutatkozott az artroMR-nél a váll elülső instabilitásával összefüggő csontos, porcos és labroligamentosus sérülések kimutatásában
[10]. Hátránya viszont az ionizáló sugárzás, melyet a közeli pajzsmirigy és emlő tekintetében mindenképpen figyelembe kell vennünk, továbbá akut diszlokáció után a csontödémát nem észleli. Amennyiben viszont az MR elvégzése valamilyen kontraindikáció miatt (pacemaker,
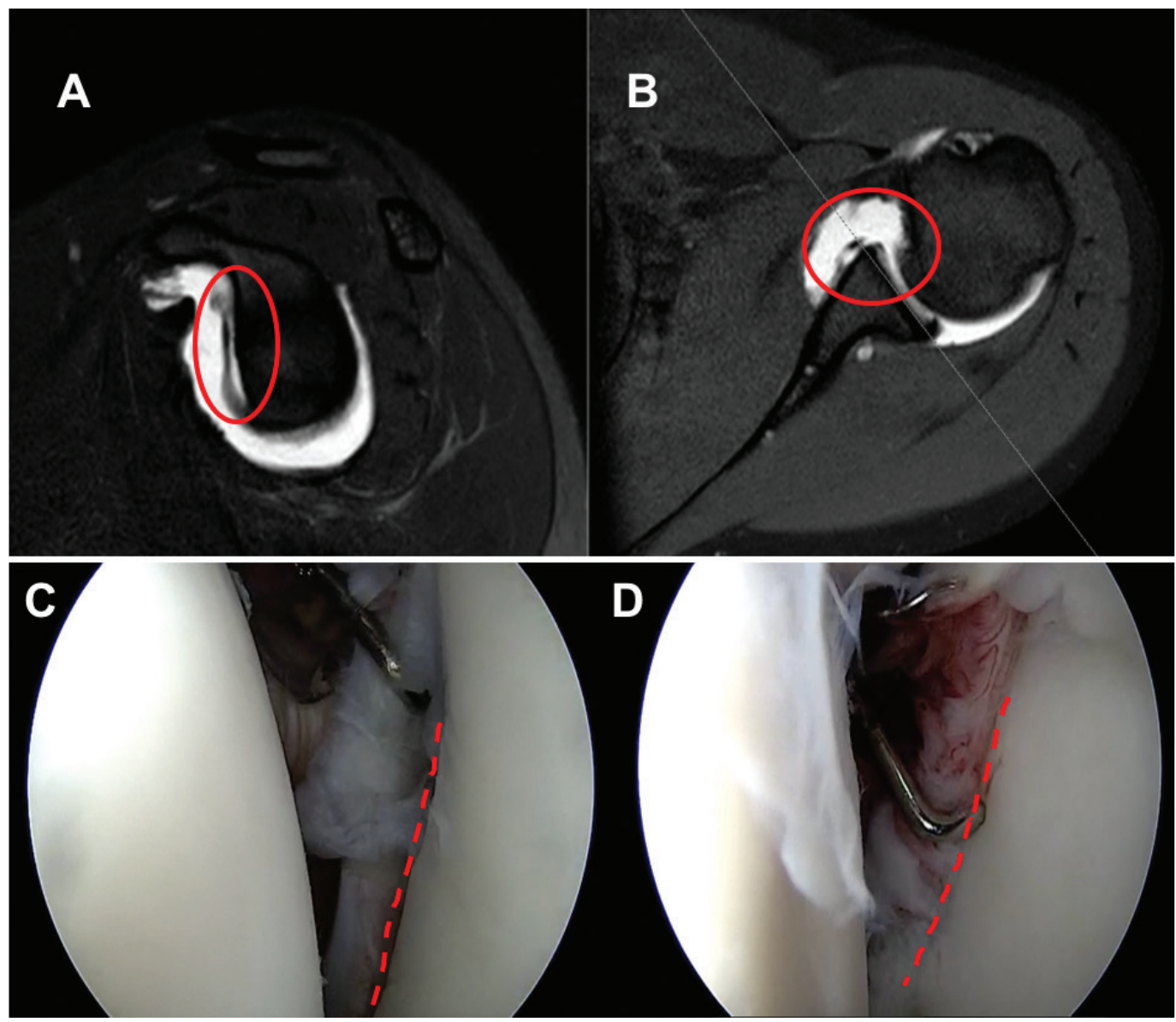

4. ábra

ALPSA-laesio

A megfelelően disztendált ízületben a sagittalis (A) és horizontális (B) metszetben jól látható, ahogy a csontos glenoidtól a labrum glenoidale és a periosteum elemelkedik (bekarikázott terület). Alatta a perioperatív artroszkópos képek láthatók. C) Horoggal elemelhető a nagy méretủ, leszakadt labrum és a hozzá kapcsolódó periosteum. D) A visszarögzítést követően a labrum már nem emelhető el horoggal

ALPSA $=$ anterior labral periosteal sleeve avulsion 
más, MRI-vel nem kompatibilis beültetett orvostechnikai eszközök, klausztrofóbia, testalkat, ízületközeli fémszerkezetek) nem kivitelezhető, mindenképpen jó és megbízható alternatív megoldás lehet.

A konvencionális MR-vizsgálatnak azonban nem csak a fenti sérülések esetében korlátozott a szenzitivitása és a specificitása, hanem a vállízületi instabilitást okozó labroligamentosus komplex speciális patológiáinak megítélése esetén is [7]. A vállízületi unidirekcionális instabilitásokat két nagy csoportra oszthatjuk: elülső és hátsó instabilitásra. Az esetek több mint 90\%-ában elülső, anteroinferior diszlokáció az oka a vállinstabilitásnak [11]. A vállízület szalagjai - legfóképpen az alsó glenohumeralis szalag - fontos szerepet játszanak a vállízület passzív stabilizációjában. A labrum glenoidale nemcsak a szalagok tapadásául szolgál, hanem megnöveli a fossa glenoidale mélységét, és ezáltal jobban stabilizálja a humerusfejet. Trauma esetén szakadása bekövetkezhet, amikor a vongált ízületi szalag magával rántja.

Számos anteroinferior labroligamentosus laesiót ismerünk. Ezek közül a klasszikusnak mondható Bankart-laesiót ismerik fel a leggyakrabban, amely az anteroinferior labrum leszakadását jelenti annak szalagrendszerével együtt. Nehezebben és ritkábban kerül felismerésre a Perthes- (az elülső labrum leválik a csontos glenoidról, de parciálisan a scapulához kapcsolódik a periosteumával) [12], az ALPSA- [13], valamint a SLAP- (superior labral tear from anterior to posterior) laesio [14]. Konvencionális MR-vizsgálattal a 'biceps pulley' sérülése is nehezen detektálható. A glenohumeralis szalagok fontos szerepet játszanak a stabilitásban [15]. A 'glenolabral articular disruption' (GLAD) laesio felületes szakadást jelent az elülső labrumon, amelyhez hozzákapcsolódik az ízületi porc egy kis darabja capsuloperiostealis leválás nélkül $[10,16]$. A fenti patológiák ritkábban kerülnek felismerésre, főként az anatómiai struktúrák szoros elhelyezkedése miatt, valamint azért, mert speciális pozicionálási beállítást igényelnek az MR-vizsgálat során. Ezenkívül a vállízületi instabilitás miatt kialakult fájdalmak hátterében álló patológiák mútét előtti pontos ismerete elengedhetetlen a mütéti terv felállításához.

A direkt módon bejuttatott kontrasztanyag használata biztonságos [17], szétoszlik az ízületben, kitöltve az esetleges patológiás tereket is, vagy teljes vastagságú szakadás során kijut az ízületból, megmutatva a szakadás helyét. Fontos még a kontrasztanyag disztendáló funkciója, mely az ízületben lévő terek tágításával javítja a képalkotás részletgazdagságát.

A megfelelő szekvenciák kiválasztása nagyban meghatározza a vizsgálat minőségét. A klasszikus $\mathrm{T}_{1}$-súlyozott képek jól ábrázolják az anatómiai helyzetet, és a zsír magas jeladásából adódóan a zsíros képletek, illetve az izomatrófiával járó zsíros infiltráció jól értékelhető rajtuk. Az MR-artrográfiában az alapvető szekvencia a $T_{1}$-súlyozott FatSat zsírelnyomott szekvencia. Mivel az artrográfia során beadott, gadolíniumtartalmú kontrasztanyag magas jeladású a $\mathrm{T}_{1}$-képeken (csökkenti a $\mathrm{T}_{1}$-relaxációs időt), ha FatSat-zsírelnyomást alkalmazunk, akkor a kontrasztanyag által kitöltött terek és laesiók jól elkülönülnek a többi struktúrától. A PD-súlyozott képek nagyon hasznosak a musculoskeletalis képalkotásban: a $\mathrm{T}_{1}$-hez hasonlóan jó anatómiai részletességgel bírnak, mindemellett pedig a folyadéktereket és ödémás területeket is képesek kiemelni, jól jelezve a patológiás régiót. A PDszekvencia továbbá a porcfelszínek pontos megítélésének alapja, illetve jól tudja ábrázolni a szalagrendszereket, a meniscusokat és a labrumot is. Tekintettel azonban arra, hogy a kis méretú labrumon még kisebb laesiókat keresünk, melyek ízületi distensio nélkül nem ábrázolódnak jól, az MR-artrográfia és a $\mathrm{T}_{1}$-súlyozott FatSat-szekvencia több információval bír. Az ödémás területek látványosabb kimutatására különféle zsírelnyomásos technikák állnak rendelkezésünkre. STIR-szekvenciával homogén zsírelnyomás érhető el a vizsgálati régióban. A FatSat-technikával nem érhető el teljesen homogén zsírelnyomás, ez a szekvencia azonban gyorsabban kivitelezhető, kevesebb a képeken a zaj, és a beadott kontrasztanyagot is magas jeladással ábrázolja. A gradiensechó-szekvenciák használata gyakran opcionális; jól ábrázolják például a kis meszesedéseket is, ám érzékenyek a különböző, fémeszközök keltette mágneses inhomogenitásokra. Fémeszközök esetében a spinechó-szekvenciák ( $\mathrm{T}_{1^{-}}, \mathrm{T}_{2^{-}}, \mathrm{PD}$-súlyozott szekvenciák) nyújtanak kevésbé mútermékes képet, a zsírelnyomásos technikák közül pedig a FatSat helyett a STIR-szekvencia ad kevesebb artefaktumot [18].

Az elvégzett vállízületi artro-MR-ek száma 29 volt, melyek közül 9 betegnél történt mútéti beavatkozás. Ennek magyarázata lehet, hogy a részletes radiológiai információk alapján biztosabban dönti el a sebész, hogy az adott eltérés operatív módon orvosolható-e, csökken a „diagnosztikus” beavatkozások száma.

A kontrasztanyag beadása a vállízületbe röntgen-képerősítő vezérlésével történt. A radiológiai leírások alapján a kontrasztanyagot 26 esetben $(89,9 \%)$ megfelelően sikerült bejuttatni a vállízületbe, kielégítő distensiót érve el ezzel. Ám a képerősítő és a sebészi gyakorlat ellenére is elöfordult 3 esetben $(10,1 \%)$, hogy a kontrasztanyag nem megfelelő helyre került beadásra, vagy a beadás után nem értünk el megfelelő distensiót. Ennek tudatában fontos kiemelni, hogy a vizsgálat végzéséhez elengedhetetlen olyan szakember jelenléte, aki a megfelelő beadási technikát képalkotó segítségével [19] megbízhatóan tudja alkalmazni.

A mütétek során felállított és a képalkotó elemzése után megállapított diagnózisok 8 esetben $(88,9 \%)$ teljes mértékben megegyeztek. Egy alkalommal szerepelt a radiológiai leírásban teljes vastagságú rotátorköpeny-szakadás, ez azonban az artroszkópia során nem mutatkozott. Balich és mtsai 222 páciensen végeztek konvencionális MR- és artroszkópiás összehasonlító vizsgálatot. A szenzitivitás 84-96\%, míg a specificitás 94-98\% közötti volt a teljes szakadások tekintetében, míg a parciális 
szakadások felismerése esetén a szenzitivitás 35-44\%, a specificitás pedig 85-97\% között változott [20].

Ferrari és mtsai 44, supraspinatus laesióval rendelkezô beteg mütéti leletét hasonlították össze az MR-artrográfiás eredményükkel. Az artro-MR 43 esetben megegyezett a mútéti leírással, és mindössze 1 fals negatív diagnózis született, amelynél tévesen tendinosist írtak le a bursalis oldalon egy parciális szakadás helyett [21]. Waldt és mtsai 2007-ben 275 beteg bevonásával végeztek vizsgálatot, melyben intraarticularisan adott kontrasztanyaggal végzett MR-artrográfia eredményeit hasonlították össze az artroszkópos mútéti diagnózissal. Teljes vastagságú szakadások esetében a szenzitivitás $96 \%$, a specificitás 99\% volt, míg részleges szakadások esetén is igen kiemelkedő, 80\%-os szenzitivitás és 97\%-os specificitás volt kimutatható [2].

Az MR-artrográfia magas szenzitivitással és specificitással rendelkezik traumás unidirekcionális vállficam után kialakult glenoid labrum szakadások diagnosztizálásában is. Egy 116 betegból álló vizsgálatban Saba és mtsai a traumás vállficam után kialakult labrumlaesiók diagnosztikus pontosságát hasonlították össze artro-MR és artroszkópia által. Az MR-artrográfia szenzitivitása az összes típusú labrumszakadásra vetítve 93\%, míg specificitása 96\% volt az artroszkópiához viszonyítva. A Bankart-laesióé 100\%, a Perthes-laesióé 71,4\%, míg az ALPSA esetén 91\% volt a szenzitivitás. A legtöbb esetben Bankart-laesio volt diagnosztizálható [22].

\section{Következtetések}

Elmondható, hogy mint minden invazív beavatkozásnak, az artro-MR-nek is vannak elönyei és hátrányai egyaránt. Hátránya, hogy a kontrasztanyag beadása az ízületbe tûszúrással történik, mely a betegnek fájdalmat okoz. A beadott kontrasztanyag a mennyisége miatt feszít, diszkomfortot, egyes esetekben határozott fájdalmat idézhet elő, melyet nem minden beteg fogad el. A kontrasztanyag beadását a sterilitási szabályok betartása mellett végezzük, ám - mint minden, ízületbe történő szúrás esetén - minimálisan, de fennáll a iatrogén fertőzések veszélye. A vizsgálat előkészítő szakaszához (első fázis), vagyis a kontrasztanyag direkt ízületbe juttatásához elengedhetetlen az ízületi szúrásokban gyakorlott ortopéd sebész vagy az invazív radiológiában jártas radiológus. Allergiás reakciót eddigi gyakorlatunkban nem tapasztaltunk, egy esetben volt 3-4 napig perzisztáló fájdalomról beszámoló beteg, és egy esetben volt, hogy a beteg az ízületi szúrás miatt utasította vissza a vizsgálatot.

Ezek mellett az ízületbe adott kontrasztanyag disztendáló hatása révén a készülő felvételek részletgazdagabbak, melyek a diagnosztikát segítik. Pontosabb diagnózissal könnyebb a kezelési irány meghatározása, csökkenhet a diagnosztikus artroszkópiák száma. Bár az ízületbe adott kontrasztanyag invazívvá teszi a vizsgálatot, egy ízületi szúrás, valamint a kontrasztanyag-kivá- lasztás kisebb megterhelést jelent a beteg számára, mint egy artroszkópos mútéti beavatkozás; a retrospektív módon történő, betegeket érintő haszon számszerü kifejezése és elemzése nem képezte részét a jelen tanulmánynak. Emellett a pontos preoperatív képalkotó a beavatkozás tervezésében is sokat segít, pontosabb mútét végezhető kevesebb, mútét közbeni improvizációval, ami csökkentheti a mútéti időt és a beteg mútéti megterhelését. Mivel az artrográfiás vizsgálat során az MR-készülékben töltött idő megegyezik a natív MR-vizsgálat idejével, az nem jelent többletterhelést a képalkotó diagnosztikai részlegnek.

Anyagi támogatás: A szerzők a közlemény megírásával kapcsolatban nem részesültek anyagi támogatásban.

Szerzői munkamegosztás: S. I.: A közlemény megírása, betegvizsgálat, kontrasztanyag beadása, a betegek mütéti kezelése. N. Á.: Adatmenedzsment, betegvizsgálat, részvétel a közlemény megírásában. Sz. A., K. Gy.: Betegvizsgálat, a betegek mütéti kezelése. H. A., K. D. T., Zs. Gy., K. I.: MR-artro-leletezés, a radiológiai szakrész megírása. A. I.: Betegvizsgálat, a közlemény szakmai véleményezése, a betegek mútéti kezelése. S. G.: Betegvizsgálat, kontrasztanyag beadása, a betegek mütéti kezelése, a kézirat szakmai véleményezése, részvétel a közlemény megírásában. A cikk végleges változatát valamennyi szerző elolvasta és jóváhagyta.

Érdekeltségek: A szerzőknek nincsenek anyagi, személyes vagy egyéb érdekeltségeik.

\section{Irodalom}

[1] Pavic R, Margetic P, Bensic M, et al. Diagnostic value of US, MR and MR arthrography in shoulder instability. Injury 2013; 44(Suppl 3): S26-S32.

[2] Waldt S, Bruegel M, Mueller D, et al. Rotator cuff tears: assessment with MR arthrography in 275 patients with arthroscopic correlation. Eur Radiol. 2007; 17: 491-498.

[3] Crim JR. Specialty imaging: arthrography. 2nd edn. Elsevier, Amsterdam, 2018. [E-Book]

[4] Jacobson JA, Lin J, Jamadar DA, et al. Aids to successful shoulder arthrography performed with a fluoroscopically guided anterior approach. Radiographics 2003; 23: 373-379.

[5] Rutten MJ, Collins JM, Maresch BJ, et al. Glenohumeral joint injection: a comparative study of ultrasound and fluoroscopically guided techniques before MR arthrography. Eur Radiol. 2009; 19: 722-730

[6] Elentuck D, Palmer WE. Direct magnetic resonance arthrography. Eur Radiol. 2004; 14: 1956-1967.

[7] Llopis E, Montesinos P, Guedez MT, et al. Normal shoulder MRI and MR arthrography: anatomy and technique. Semin Musculoskelet Radiol. 2015; 19: 212-230.

[8] Lefebvre G, Badr S, Morel V, et al. How to do a knee MR scan? [Comment je fais une IRM de genou?] Journal d'imagerie diagnostique et interventionnelle 2019; 2: 182-186. [French]

[9] Daffner RH, Weissman BN, Bennett DL, et al. Expert Panel on Musculoskeletal Imaging. ACR appropriateness criteria stress/ insufficiency fracture, including sacrum, excluding other vertebrae. American College of Radiology, Reston, VA, 2008. 
[10] Acid S, Le Corroller T, Aswad R, et al. Preoperative imaging of anterior shoulder instability: diagnostic effectiveness of MDCT arthrography and comparison with MR arthrography and arthroscopy. Am J Roentgenol. 2012; 198: 661-667.

[11] Dumont GD, Russell RD, Robertson WJ. Anterior shoulder instability: a review of pathoanatomy, diagnosis and treatment. Curr Rev Musculoskelet Med. 2011; 4: 200-207.

[12] Wischer TK, Bredella MA, Genant HK, et al. Perthes lesion (a variant of the Bankart lesion) MR imaging and MR arthrographic findings with surgical correlation. Am J Roentgenol. 2002; 178: 233-237.

[13] Neviaser TJ. The anterior labroligamentous periosteal sleeve avulsion lesion: a cause of anterior instability of the shoulder. Arthroscopy 1993; 9: 17-21.

[14] Khazzam M, Jordanov MI, Cox CL, et al. SARL: Shoulder acronyms. A review of the literature. Arthroscopy 2011; 27: 542555 .

[15] Beltran J, Bencardino J, Mellado J, et al. MR arthrography of the shoulder: variants and pitfalls. Radiographics 1997; 17: 14031415.

[16] Waldt S, Burkart A, Imhoff AB, et al. Anterior shoulder instability: accuracy of MR arthrography in the classification of anteroinferior labroligamentous injuries. Radiology 2005; 237: 578583.
[17] Schulte-Altedorneburg G, Gebhard M, Wohlgemuth W, et al. MR arthrography: pharmacology, efficacy and safety in clinical trials. Skeletal Radiol. 2003; 32: 1-12.

[18] Goh CK, Peh WC. Pictorial essay: pitfalls in magnetic resonance imaging of the shoulder. Can Assoc Radiol J. 2012; 63: 247259.

[19] Sethi PM, Kingston S, Elattrache N. Accuracy of anterior intraarticular injection of the glenohumeral joint. Arthroscopy 2005; 21: 77-80.

[20] Balich SM, Sheley RC, Brown TR, et al. MR imaging of the rotator cuff tendon: interobserver agreement and analysis of interpretive errors. Radiology 1997; 204: 191-194.

[21] Ferrari FS, Governi S, Burresi F, et al. Supraspinatus tendon tears: comparison of US and MR arthrography with surgical correlation. Eur Radiol. 2002; 12: 1211-1217.

[22] Saba L, De Filippo M. MR arthrography evaluation in patients with traumatic anterior shoulder instability. J Orthop. 2017; 14: 73-76.

(Sallai Imre dr., Budapest, Üllöi út 78/B, II. emelet, 1082 e-mail: sallai.imre@semmelweis-univ.hu)

\section{"Iter est quacumque dat prior vestigium." (Mindenütt út van, ahol egy előtted járó nyomot hagy.)}

A cikk a Creative Commons Attribution 4.0 International License (https://creativecommons.org/licenses/by/4.0/) feltételei szerint publikált Open Access közlemény, melynek szellemében a cikk bármilyen médiumban szabadon felhasználható, megosztható és újraközölhető, feltéve, hogy az eredeti szerző és a közlés helye, illetve a CC License linkje és az esetlegesen végrehajtott módositások feltüntetésre kerülnek. (SID_1) 